\title{
Attaining New Knowledge on Inclusive Education: A Case Study of Students' Voices
}

\author{
By Jorun Buli-Holmberg * \\ Leda Kamenopoulou ${ }^{\dagger}$
}

\begin{abstract}
The purpose of this research was to gather the voices of students undertaking a Master's programme on Special and Inclusive Education by exploring their perceptions of what they have learned about inclusive education during the programme. We used the case study approach in order to investigate the students' perceptions and reflections on their learning outcomes related to how they understand inclusive education, with specific focus on the students' awareness of change, how they understand the principle of inclusion and their explanations of inclusive education. Ten students participating in the Master's programme took part in the study. Data were collected with an openended questionnaire tool that students completed half way in their studies. Students' qualitative statements were analysed through an inductive approach and three main themes emerged: "understanding of inclusive education" "awareness of change", and "success criteria for practicing inclusive education". Results suggest that the student group as a whole considered that they had attained new knowledge, expanded and nuanced their understanding of inclusive education, and the majority of the students were aware of how they had enriched their knowledge and were able to state how they will go about implementing inclusive education in practice.
\end{abstract}

Keywords: Diverse Needs, Inclusion/Inclusive Education, Policy and Practice, Student teacher perceptions.

\section{Introduction}

The present case study investigated 10 students' understanding of inclusive education during their participation in a Master's Programme in Special and Inclusive Education (MASIE), and the possible changes to their understanding. MASIE intends to meet the needs for developing teacher competence and understanding of inclusive education with a specific focus on the education for pupils with special needs, and to enhance and support practice. The new knowledge the students attain through their master's studies will be an essential factor in their future competence to implement inclusive education in practice. The Salamanca Statement (UNESCO, 1994, p. 40) states that: "Appropriate preparation of all educational personnel stands out as a key factor in promoting progress towards inclusive schools." Since the purpose of MASIE is to build teachers' competence in inclusive education and to enhance practice, we wanted to investigate in detail the new knowledge, if any, that the students attain through

\footnotetext{
* Associated Professor in Special and Inclusive Education, University of Oslo, Norway.

$\uparrow$ Senior Lecturer in Special and Inclusive Education, School of Education, University of Roehampton, London, UK.
} 
their studies, in what ways they think their understanding may be changing and how they expect this new knowledge to influence what they do in practice.

In order to provide the context for this case study, we will first set out some of the core elements of the curriculum of MASIE. Norwich (2005) describes inclusive education as a philosophy that provides all students with learning community membership and opportunities for academic and social achievement, based on the principle that students have unique needs that should be valued. Inclusion in education is rooted in the principle of the human right to education stated in Article 26 of the 1948 Universal Declaration of Human Rights as follows: "Everyone has the right to Education. [...] Education shall be directed to the full development of the human personality and to the strengthening of respect for human rights and fundamental freedoms."

This statement is based on values such as equality, diversity and social coherence as the main goals for education, in a school where all children have equal opportunities to participate and the right to be treated equally. These values have also been placed at the core of the curriculum for MASIE. In our case study we wanted not only to focus on students' changing perceptions regarding education and placement in a school for all, but also their understanding of the core values behind inclusion. We moreover wanted to investigate to what extent the students were becoming aware of these values.

The Salamanca statement further highlights the principles behind Inclusion as concerning placement of all children in regular school systems, and the importance of enabling the school systems to include all children regardless of individual differences (UNESCO, 1994). The Salamanca statement is explored in the MASIE from different angles. For example, in relation to the need to recognise education for all in each nation's policy, the Salamanca statement (UNESCO, 1994, p. 44) says: "The development of inclusive schools as the most effective means for achieving education for all must be recognized as a key government policy and accorded a privileged place on the nation's development agenda." This has implications for policy development in all countries in order to ensure that educational systems give equal opportunities to all children. Educational policies in the Global North and South is one of the central issues explored in MASIE, and stressing the need for building up national educational policies that reflect the principles of inclusive education is very relevant since our students come from different parts of the world and represent very different policy contexts.

Furthermore, in relation to improvements needed in practice, the Salamanca statement (UNESCO, 1994, p. 6) stresses the challenge of "developing a child centred pedagogy capable of successfully educating all children, including those who have serious disadvantages and disabilities." The development of pedagogies built around each pupil's abilities is highlighted here, and the implication for developing an inclusive school is to implement a child centred pedagogy educating all children based on their diverse needs. Accordingly, the school system must give everyone equal opportunities to have access to teaching and learning, and the schools and teachers have to be aware of the pupils' differences. This assumes that human differences are taken as the norm, hence 
teachers must be able to adapt to the diverse needs of each child (Davis \& Watson, 2001). A central goal of inclusive education is not only to give each child access to regular education, but to also meet all children's diverse needs in an inclusive context. In the MASIE these values are also explored with students as important prerequisites for inclusion.

Given the above context, our main research question was: What new knowledge do students acquire about inclusive education during their participation in a Master's Programme on Special and Inclusive Education? And the following were the sub-questions:

1. How do students understand inclusive education?

2. Do students think they have changed their understanding of inclusive education?

- If yes, in what ways?

3. How do students think that inclusive education can be implemented in (their) practice?

\section{Literature Review}

\section{The Need for Developing Competence in the Field of Inclusive Education}

How teachers understand inclusive education often depends on their level of knowledge and skills. Lawson, Parker, and Sikes (2006) argue that the translation of policy into practice is shaped by the way individuals understand inclusive education. Darling - Hammond (2016) argues that building teachers' competence is a significant pre-requisite for successfully implementing reforms in schools and improving practice. A body of research shows that teachers' prior knowledge and understanding of inclusion is a key factor to its successful implementation (for a review of the relevant literature, see Kamenopoulou, BuliHolmberg, \& Siska, 2015). Moreover, teachers' attitudes to and understanding of inclusion have been shown to change after training or further studies on inclusion and special needs education (Cologon, 2012; Boyle, Topping, \& Jindal-Shape, 2013; Costello \& Boyle, 2013; Lawson, Norwich, \& Nash, 2013; Cameron \& Jotveit, 2014). This research indicates that teacher competence influences the teachers' understanding of inclusive education and how they implement it in practice.

Furthermore, Clandinin (1995) stresses the need for teachers to acquire skills in the translation of theory on good teaching into practice. Teachers need both practical tools for managing classroom situations and a broader theoretical view on education grounded in pedagogy, psychology, and sociology (Korthagen, 2001). According to the Schön theory (1983) of the reflective practitioner, "reflection in and on actions" focuses on the need for the professional teacher to reflect on their practice. Participating in practice- oriented studies promotes practicing inclusive education in a school for all (Holmberg \& Tangen, 2000), and indicates the significance of teachers developing competence applicable in 
schools (Holmberg, 2005).

\section{The Need for a Shared Understanding of the Values of Inclusive Education}

How politicians and staff in schools understand the values of inclusive education influences how these values are translated into policy and practice. Shared understanding of the vision of inclusive education is identified as necessary for improvement in the school system (Senge, 1990). A shared vision helps to encourage and facilitate learning and inclusive education throughout all levels of the school organisation. However, when it comes to defining and sharing the vision of inclusion, there are challenges, and Norwich (2005) states that inclusion is a complex multileveled phenomenon. Booth and Ainscow (1998) view inclusion as a process of increasing the participation of learners and reducing their exclusion from curricula, cultures and communities offered by neighbourhood mainstream centres of learning. However, inclusion is often connected to people with disabilities and this is rooted in the present-day rhetoric on inclusion that stresses a long history of segregation and social oppression, and the exclusion of disabled populations (Barnes, 1997). Accordingly, disability was claimed to be social oppression and not a medical condition that can be treated or cured (Oliver, 1990). It can be argued that inclusive education is a combination of pedagogical and philosophical practices that promotes education for all. In this case, the practices ensure promotion of social unity, educational rights, sense of belonging, and learning of all children in schools together with their peers (Peters, 2007). Inclusion may be seen as an overall vision for all people, not only the disabled, concerning better quality of educational life throughout participating and belonging to the school and society (Tangen, 2003; Buli-Holmberg, 2015). However, the challenge of developing a common understanding of the vision of inclusive education is crucial to its implementation in practice (Senge, 1990; Schön, 1983; Skogen, 2014; 2015).

\section{Practicing Inclusive Education and Meeting Pupils' Diverse Educational Needs}

Thomas and Loxley (2001) state the importance of understanding policies and practices and acquiring knowledge in the field of inclusive education. In the attempt to implement inclusive education, teachers in regular schools have to make considerable adjustments in terms of delivery, content and class organisation (Snowling, 2006). Specifically, they make adjustments in order to meet the needs of learners with special educational needs. Differentiated instruction is one approach that adapts the teaching compared to the pupils learning abilities and potentials (Hoover \& Patton, 2005). Today's classroom reflects the diversity of our communities and includes a mix of students, hence the teacher needs to search for strategies that address all pupils' needs and implement differentiated instruction (Tomlinson, et al., 2003). Inclusive education therefore requires teachers to identify the individual needs of each pupil, 
because in every classroom all pupils are different, and the differences can be managed using a variety of approaches, adaptations to instruction and assessment, and additional support provided to some students (Buli-Holmberg, 2015).

\section{Methodology}

The case study research design was used with the purpose of exploring the students' perceptions of "what they learn about inclusive education during their participation in MASIE." The strength of the case study approach is the possibility to go deeper into the students' understanding of the phenomena (Baxter \& Jack, 2008; Yin, 2003). The unit of this case study was ten students participating in MASIE. Out of the 16 months of the duration of the Master's programme the questionnaire was administered half way through the study. The student group represented different cultures and educational systems as they came from different countries of Europe, Asia, South America, and Africa. Their participation in the study was voluntary and anonymous. Ethical considerations were observed according to the BERA ethical guidelines (2011).

An open-ended questionnaire was developed to explore how students gain knowledge and more specifically, how they understand the concept of inclusive education during their Master's Programme. The questions concerned the students' understanding of inclusion and how they thought their understanding had changed, if at all, halfway through their studies. Thematic analysis of the data formed the basis for the interpretations and helped establish a meaningful link between empirical data and analysis (Braun \& Clarke, 2006). Themes were developed based on the empirical data and the previous literature. The themes were intended to provide an understanding of the students' perception of attaining new knowledge, and how they reflect on their learning outcomes halfway through the duration of their programme. The objective of the analysis was to categorise the data, and to select themes that would illuminate all aspects of the data that was relevant in order to answer the research questions (Kvale, 1996; Willing, 2008). Validity was safeguarded throughout the analysis by reviewing data several times, and the meaningful elements from the students' answers to the questions were identified based on the pre-selected themes (Braun $\&$ Clarke, 2006). The goal was to categorise the students' perspectives while at the same time being "open" to what they wrote, (Willig, 2008), which gave us the opportunity to see the results from multiple viewpoints. Moreover, descriptions of context and methods for data collection and analysis provide an opportunity to consider a transfer value (Baxter \& Jack, 2008). As a result of the analysis, 3 themes arose, which are listed in Table 1 together with their respective sub-themes. 
Table 1. Themes and Sub-Categories Emerging from the Analysis

\begin{tabular}{|c|c|c|}
\hline $\begin{array}{l}\text { The students' } \\
\text { understanding of } \\
\text { inclusive education }\end{array}$ & $\begin{array}{c}\text { The students' awareness } \\
\text { of change to their } \\
\text { understanding }\end{array}$ & $\begin{array}{l}\text { The students' success criteria } \\
\text { for practicing Inclusive } \\
\text { Education }\end{array}$ \\
\hline 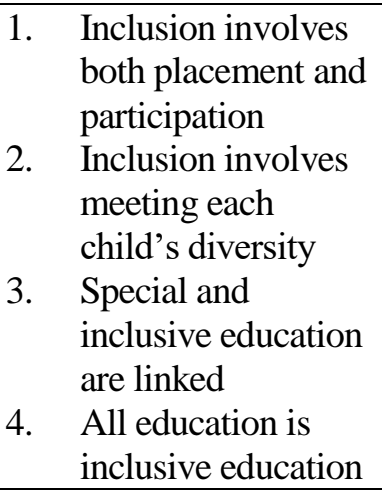 & $\begin{array}{l}\text { 1. No change: Same } \\
\text { understanding as } \\
\text { before } \\
\text { 2. Change: Enriched, } \\
\text { deeper and broadened } \\
\text { understanding }\end{array}$ & $\begin{array}{l}\text { 1. Change of policy and } \\
\text { practice } \\
\text { 2. Goal for all countries } \\
\text { working towards } \\
\text { inclusion } \\
\text { 3. Differentiated instruction, } \\
\text { organisation and } \\
\text { procedures } \\
\text { 4. Inclusive education is } \\
\text { challenging, but realistic } \\
\text { in practice }\end{array}$ \\
\hline
\end{tabular}

\section{Presentation and Discussion of Findings}

\section{First Theme: Understanding of Inclusive Education}

The first theme concerns the students' understanding of inclusive education. As we have seen, a shared understanding of the concept of inclusive education is an important factor in the process of its implementation in to practice. The presentation of this theme is structured according to the four subthemes emerging from the data in relation to participants' views about what inclusion involves, namely, 1) placement and participation, 2) meeting each child's diversity, 3) it is linked to special education, and 4) all education is inclusive education. The presentation of these subthemes is accompanied by a discussion of the relevant literature.

Placement and Participation. An example of a participant statement that was grouped under this sub-category is the following:

S 3: My understanding about inclusive education has changed in the sense that [I know think that] inclusive education can take place in any educational setting, but it involves participating of all not only placement.

This statement illustrates how this student has expanded their understanding of inclusion from mere placement, to placement and full participation. Generally, most of the international educational policy documents and research articles highlight placement as a key feature of inclusion. The Salamanca Statement first emphasised the need for governments all over the world to ensure all children are enrolled in regular schools (UNESCO, 1994). Booth and Ainscow (1998) describe placement in mainstream schools as a form of avoiding the exclusion of pupils with special needs. On the other hand, Norwich (2005) argues that participation and belongingness are also important elements of inclusion reminding us that mere mainstream placement is not enough for inclusive education to succeed. 
Meeting each Child's Diversity. An example of a statement that was grouped under the second subtheme is:

S 3: Every child has unique characteristics, attitudes and learning needs, which needs to be taken care of individually.

This statement is illustrative of most students' awareness of diversity in the modern classroom and of the need for educators to meet each child's individual educational needs. This is in line with a central principle in the Salamanca Statement (UNESCO, 1994) about every child's right to have the opportunity to education and to maintain an acceptable level of learning based on their unique characteristics, abilities and learning needs. Inclusive education concerns being aware of individual differences and teaching by making adaptations according to the diverse needs of every child (Buli-Holmberg, 2015). This understanding of inclusive education assumes that individual differences are normal and learning must be adapted to the human diversity and different needs.

Special and Inclusive Education are Linked. Examples of statements grouped under this subtheme are:

S 2: Positive change: got more focused on how to include special needs children.

S 6: I learned that special and inclusive education are linked.

S 7: I think I cannot address both inclusive and special education without addressing each other, not as synonym, but as complementary. Under the umbrella of Inclusion I would place special education.

The first example suggests that the student has learned that children with special needs are the focus of inclusive education. Similarly, in the second and third examples, the learning outcome described is the understanding of the link between special and inclusive education. All the above statements clearly reflect an understanding of inclusive education as associated with the education of students with disabilities and special needs. In a previous research article (see Kamenopoulou, Buli-Holmberg, \& Siska, 2015), we discussed extensively the debate around the meaning of inclusive education and how it relates to special education. In a nutshell, the Salamanca Statement (UNESCO, 1994) first introduced the idea of inclusive education for children with disabilities (Vislie, 2003; Nilholm, 2006) and since then, inclusion has been associated with those groups of children (Hodkinson, 2010; Sikes, Lawson, \& Parker, 2007). Although it is now accepted that inclusive education is a much broader concept that entails removal of barriers for all children, not just those with disabilities (Booth, 2000; Stubbs, 2008), teachers' competence in special needs education and specialist knowledge are thought to be necessary for them to be able to include pupils with special needs (Schôn, 1983; Senge, 1990; Cologon, 2012; BuliHolmberg, 2015). This is challenging, because teaching children with special needs requires specific knowledge and skills that are not part of all teachers' 
education (Fuchs \& Fuchs, 1993). Mintz and Wyse (2015) stress that lack of knowledge about specific categories in teacher education adversely affects the ability of teachers to implement inclusive education.

All Education is Inclusive Education. Finally, in the fourth subtheme we grouped statements such as:

S 8: I see more and more the idea of inclusive education as the real meaning of education in itself: An education, which is not inclusive, is not really education.

This understanding of inclusive education sees education and inclusive education as synonymous terms, and here we see awareness of a key idea behind inclusive education. Inclusive education can be simply described as a childcentred pedagogy that aims to provide a successful and high quality education to all children (UNESCO, 1994). However, it can also be argued that the terms education and inclusion are different. Education concerns teaching and learning, whereas inclusion is about belonging, participating, placement and quality of school life and students' sense of wellbeing (Booth \& Ainscow, 1998; BuliHolmberg, 2015; Karatzias, Athanasiou Power, \& Swanson, 2001; Norwich, 2005; Tangen, 2003).

\section{Summary of Theme "Understanding of Inclusive Education"}

The results from the data show that the participants understood inclusive education in four different ways, all of which reflect some of the relevant literature. The understanding of inclusion as placement and participation is central in Booth and Ainscow (1998), who view inclusion as a process of increasing adaptions to curricula and changes to cultures, and placement in the mainstream local school. Participating is also central in Norwich's perspective of inclusion, but he also brings in belongingness as an important factor (2005). The understanding of inclusive education as meeting children's diverse needs seems to reflect the need for a pedagogical practice that is varied and flexible (Peters, 2007). Students also saw inclusive education as linked to special education as per our third subtheme, and inclusion is often associated to children with disability and their opportunities to participate and contribute in school and society (Oliver, 1990; Barnes, 1997). Finally, the perception of inclusion as education for all, not only education of those children with special needs, reflects arguments about inclusion being better quality education for all pupils through participation and belonging in the school community (Booth \& Ainscow, 1998; Norwich, 2005; Tangen, 2003).

\section{Second Theme: Awareness of Change}

The second theme focusing on the students' awareness of change is a metaperspective on their own learning process and is divided in two subthemes: 1) same understanding as before and 2) change in understanding. It is noteworthy 
that only two out of ten students said they had the same understanding of inclusive education as before. The majority in the student group (8 of 10) stated they were aware of changes in their understanding, and they were able to explain how their understanding had changed.

Same Understanding as Before. Two of the students expressed the view that they had not changed their understanding of inclusive education. S 9: $M y$ view of inclusive education has not really changed. S 10: No I did not get any new opinions. These answers to the question about their awareness of change might be interpreted as follows: they already understood inclusion closely in a way similar to what they learned about inclusion through MASIE. Another reason might be that they were simply not aware of the changes, and were therefore unable to express these changes. They might have not been reflecting on their own learning process to be able to identify their own learning. There might also be a weakness with the open-ended questionnaire used, because the question about their awareness of change was simply asking them if they felt that their understanding had changed, and hence might not have helped them reflect on their understanding and any changes in it in more depth. However, the majority of the students said that they were aware of changes to their understanding, and it is to this group that we turn our attention next.

Change in Understanding. Eight of the students expressed that they have developed their understanding of inclusion during their learning process in MASIE. S 8: My understanding has improved and has been enriched. Another student expressed with other words a broader and deeper understanding of inclusion. S 4: Yes, [my understanding has changed and] it is because a broadened and deepened understanding and many other perspectives are taken into account. The changes described here concerned broadening and deepening the understanding of inclusive education. This statement is representative of most of the informants' answers, and it seems like the students had been reflecting on their learning process and identified their learning outcomes, which are both important factors in developing new knowledge and skills (Senge, 1990). Since the answer was not explained further, it is difficult to draw conclusions about what the enrichment, deepening and broadening concerns, and this was one of the weaknesses of the questionnaire tool used. The students also highlighted their learning through reflection, and that the positive experiences from reflection with others initiated personal reflection (Schön, 1983). For example, S 5: Yes, the group discussion made me reflect a lot. I had an understanding of Special and Inclusive Education, but I realised that special education is a part of inclusive education. Without knowledge of special needs education we do not know how we can move toward inclusion.

\section{Summary of Theme "Awareness of change"}

The same understanding as before and a change in understanding - enriched, deeper and broadened- were the two different points of view that emerged. There are different ways of understanding inclusion, because inclusion is a complex and multileveled phenomenon (Norwich, 2005), hence we accept that it would 
be difficult for the students to explain explicitly how they understand it and to also be able to identify any changes in their understanding. However, we felt that it was important to explore this aspect, because according to the Schön theory (1983) of the reflective practitioner, reflection is important for the development of a meta-perspective to learning and also for making the links between theory and practice of inclusive education. Building teachers' competence is a significant pre-requisite in order to implement and improve the practice of inclusive education in mainstream schools (Cologon, 2012; Darling - Hammond, 2016).

\section{Third Theme: Success Criteria for Practicing Inclusive Education}

The third theme was focused on the students' criteria for implementing inclusive education in practice, and the following subthemes emerged: 1) change of policy and practice, 2) goal for all countries working towards inclusion, 3) differentiated instruction, organisation and procedures, and 4) inclusive education is challenging, but realistic in practice. The structure of the presentation of these results and their discussion follows the four criteria for practicing inclusive education.

Change of Policy and Practice. The following quotation is illustrative of this subtheme:

S 1: I have changes my understanding of the term inclusive education in that [it] is all about change of policy and practice.

Since MASIE involves dissemination of experience and sharing of knowledge about international policies related to inclusion, it is natural that the students focused on the relationship between policy and practice. This view is also reflected in the Salamanca statement that encourages all governments to give the highest priority to policies for inclusion in education of all children regardless of individual differences or difficulties (UNESCO, 1994).

Goal for all Countries Working Towards Inclusion. The following statement captures this view:

S 2: I have learned to aim high, but work on basic things that are possible to do. Inclusion to me is still the goal for every country, but in reality no country has achieved it. That is why we cannot stop working hard on it.

The student points out their understanding of inclusion as a goal for all countries, and they moreover point out that no countries have succeeded in realising the goal in practice. The statement shows awareness of the need for continuous hard work to improve practice (Skogen, 2014) and an understanding that inclusion is not an end product, but a process (Booth \& Ainscow, 2002). This is also in line with one of the conclusions of the Salamanca Statement that the most effective way to develop inclusive schools is the recognition of inclusion as a key government policy with a central place in every nation's agenda (UNESCO, 1994). 
Differentiated Instruction, Organisation and Procedures. The following quotation is illustrative of this subtheme:

S 1: My learning outcome in [relation to] inclusive education in a nutshell is all about instruction/organisation/reorganization of structures and procedures to differentiated learning.

Differentiated instruction is proposed as an approach to teaching that is sensitive to the pupils' learning abilities and potential (Buli-Holmberg, 2015). It can be argued that differentiated instruction will also meet the need for a personalised pedagogy, which is an important aspect of inclusive education (UNESCO, 1994).

Inclusive Education is Challenging, but Realistic in Practice. Here is an example of a quotation that illustrates this subtheme:

S 6: Before I always thought that inclusive education is not realistic, but now I know that it is a challenge but possible.

It is accepted that inclusive education is challenging and connected to the consideration of quality of school life and the pupils' sense of wellbeing in the school (Karatzias, Athanasiou, Power, \& Swanson, 2001). Both inclusion and quality of school life are complex and challenging and require teacher awareness of each pupil's learning experiences and social relationships with teachers, peers, and others, and the learning situation in the school (Tangen, 2003).

\section{Summary of Theme "Success Criteria for Practicing Inclusive Education"}

In summary, answers grouped under the third theme focused on the need for changes in policy and practice, the need for all countries to work towards the goal of inclusion, the need to address diverse needs with differentiated instruction, organisation and procedures, and the awareness that inclusive education is challenging, but still possible to achieve in practice. Thomas and Loxley (2001) stress the links between policy and practice and the need for changes to policy and practice for inclusion to be achieved. Moreover some participants in this case study came from countries in Asia, South America and Africa that still have a long way to go in terms of putting in place policies for inclusive education and in terms of implementing those policies and ensuring access to education for all children. Hence for those students, their cultural background may have influenced their views. The criterion that inclusive education must be a goal for all countries, and the need to meet diverse needs with differentiation strategies are also in line with relevant literature. Teachers in regular schools have to make considerable adjustments to meet children's diverse and special educational needs (Snowling, 2006), and this requires differentiated instruction, which adapts the teaching to the pupils' learning abilities and potential (Hoover \& Patton, 2005). Finally, the view that inclusive education is realistic in practice albeit challenging seems to contradict studies 
suggesting that professionals see inclusion as utopic rather than feasible (Croll $\&$ Moses, 2000). This may be because unlike practicing teachers, the student teachers that formed our sample are more prone to thinking positively about the possibilities of inclusive education rather than focusing on the numerous practical obstacles to its implementation.

\section{Conclusion}

The purpose of this case study was to listen to the students' voices and to explore their understanding of inclusive education halfway through a Master's Programme on Special and Inclusive Education. The aim was to investigate the students' perceptions and reflections on their learning outcomes and their awareness of change, and how they understand the term inclusive education. The data were analysed through the inductive approach and organised into three themes. In terms of their understanding of inclusive education, the students described inclusive education as placement and participation, meeting diversity, linked to special education, and as education for all. In terms of the students' awareness of change, the majority believed that they had enriched and broadened their understanding during their studies. Regarding the students' success criteria for practicing inclusive education, they highlighted the following: the need for changes in policy and practice, the need for all countries to work towards inclusion, the need to address diverse needs with differentiation, and finally that inclusive education is challenging, but realistic in practice. We can therefore conclude that the student group as a whole had expanded their knowledge and understanding of inclusive education and were aware of these changes and their consequences for their future practice. The majority of the students had developed a higher level understanding of inclusive education halfway through their master's programme. They had enriched their knowledge related to inclusive education and they were moreover able to show awareness of the changes in their understanding.

In conclusion, we would like to highlight some key messages that emerged from the analysis of the students' voices in this particular case study:

- Inclusive education should be an ongoing goal for all countries, and focus on changing policy and practice.

- Inclusive education should be an overall approach for education that involves belonging and participation and concerns meeting each child's diverse needs.

- For inclusive education to be implemented in practice there is a need for differentiated instruction, organisation and procedures.

- Implementing inclusive education in practice is challenging, but is still realistic and achievable. 


\section{References}

Barnes, C. (1997). A legacy of Oppression: A history of Disable in Western Culture. In L. Barton, \& M. Oliver (Ed.) Disability Studies: Past Present and Future (pp. 3-24). Leeds: Disability Press.

Baxter, P., \& Jack, S. (2008). Qualitative case-study methodology: Study design and implementation for novice researchers, 13, 544-559.

Booth, T. (2000). Inclusion and exclusion policy in England: who controls the agenda? In F. Armstrong, D. Armstrong, \& L. Barton (Eds.) Inclusive Education: Policy contexts and comparative perspectives (pp.78-98). London: David Fulton.

Booth, T., \& Ainscow, M. (1998). From Them to Us: An International Study of Inclusion in Education. London: Routledge.

Booth, T., \& Ainscow, M. (2002). Index for Inclusion: Developing learning and participation in schools. Bristol: Centre for Studies on Inclusive Education.

Boyle, C., Topping, C., \& Jindal-Snape, D. (2013). Teachers' attitudes towards inclusion in high schools. Teachers and Teaching: theory and practice, 19(5), 527-42.

Braun, V., \& Clarke, V. (2006). Using thematic analysis in psychology. Qualitative Research in Psychology, 3(2), 77-101.

Buli- Holmberg, J. (2010). Kompetanseheving gjennom praksisrelatert etter og videreutdanning som ledd i kvalitetsutvikling [Education through practice-related education as a part of quality improvement in schools]. In J. Buli-Holmberg, \& S. Nilsen (Eds) Kvalitetetsutvikling av tilpasset opplaring (pp. 113-134). Oslo: Universitetsforlaget.

Buli-Holmberg, J. (2015). Lærerens rolle i spesialundervisning [The teacher role in Special Education]. In J. Buli-Holmberg, S. Nilsen \& K. Skogen, (Eds.). Kultur for tilpasset opplaering (pp.83-107). Oslo: Cappelen Damm Akademisk.

Cameron, D.L., \& Jortveit, M. (2014). Do different routes to becoming a special educator produce different understandings of the profession and its core concepts? European Journal of Special Needs Education 29(4), 559-70.

Clandinin, D.J. (1995). Still learning to teach. In T. Russell \& F. Korthagen (Eds.), Teachers who teach teachers (pp. 25-31). London/Washington: Falmer Press.

Cologon, K. (2012). Confidence in their own ability: postgraduate early childhood students examining their attitudes towards inclusive education. International Journal of Inclusive Education, 16(11), 1155-73.

Costello, S., \& Boyle, C. (2013). Pre-service Secondary Teachers' Attitudes towards Inclusive Education. Australian Journal of Teacher Education, 38(4), 129-43.

Croll, P., \& Moses, D. (2000). Ideologies and utopias: education professionals' views of inclusion. European Journal of Special Needs Education, 15(1), 1-12.

Darling-Hammond, L. (2016). Research on Teaching and Teacher Education and Its Influences on Policy and Practice. Educational Researcher, 45(2), 83-91.

Davis, J.M., \& Watson, N. (2001). Where Are the Children's Experiences? Analysing Social and Cultural Exclusion in 'Special' and 'Mainstream' Schools. Disability \& Society, 16(5), 671-687.

Fuchs, L.S., \& Fuchs, D. (1993). Formative evaluation of academic progress: how much growth can we expect? School Psychology, 22, 27-49.

Hodkinson, A. (2010). Inclusive and special education in the English educational system: historical perspectives, recent developments and future challenges. British Journal of Special Education, 37(2), 61-7.

Holmberg, B. (2005). Theory and Practice of Distance Education. London and New York: Routledge.

Holmberg, J.B., \& Tangen, R. (2000). Kompetanseutvikling og fleksibel laering. 
Erfaringer med og behov for spesialpedagogisk utdanning [Competence development and flexible learning. Experiences with and needs for special education education]. Oslo: Unipub, Universitetet i Oslo.

Hoover, J., \& Patton, J.R. (2005). Differentiating Curriculum and Instruction for English-Language Learners with Special Needs. Intervention in School and Clinic: a journal of the Hammill Institute on Disabilities, 40(4), 231-235.

Kamenopoulou, L., Buli-Holmberg, J., \& Siska, J. (2015). An exploration of student teachers' perspectives at the start of a post-graduate study programme on Inclusion and Special Needs Education. International Journal of Inclusive Education, 20(7), 743-755.

Karatzias, A., Athanasiou, V.P., Power, K.G., \& Swanson, V. (2001). Quality of school life: A cross-cultural study of Greek and Scottish Secondary Pupils. Euro. J. Edu. 36(1), 91-105.

Korthagen, F.A.J. (2001). Linking practice to theory: The pedagogy of realistic teacher education. Paper presented at the Annual Meeting of the American Educational Research Association: Seattle.

Kvale, S. (1996). Interviews: An Introduction to Qualitative Research Interviewing. Sage Publications.

Lawson, H., Parker, M., \& Sikes, P. (2006). Seeking stories: reflections on a narrative approach to researching understandings of inclusion. European Journal of Special Needs Education, 21(1), 55-68.

Lawson, H., Norwich, B., \& Nash, T. (2013). What trainees in England learn about teaching pupils with special educational needs/disabilities in their school-based work: the contribution of planned activities in one-year initial training courses. European Journal of Special Needs Education, 28(2), 136-55.

Mintz, J., \& Wyse, D. (2015). Inclusive pedagogy and knowledge in special education: addressing the tension. International Journal of Inclusive Education, 19(11), 1161-1171.

Nilholm, C. (2006). Special education, inclusion and democracy. European Journal of Special Needs Education, 21(4): 431-445.

Norwich, B. (2005). Inclusion: is it a matter of evidence about what works or about values and rights? Education, 3(13), 51-56.

Oliver, M. (1990). The Individual and Social Models of Disability. The Disability Studies Archive UK, Centre for Disability Studies, University of Leeds. Retrieved from http://bit.ly/2zrtZaW.

Peters, S. (2007). "Education for all?" A historical analysis of international inclusive education policy and individuals with disabilities. Journal of Disability Policy Studies, 18(2), 98-108.

Senge, P.M. (1990). The Fifth Discipline. London: Century Business.

Schøn, D.A. (1983). Reflective Practitioner: How Professionals Think in Action. United States of America: Basic Books.

Sikes, P., Lawson, H., \& Parker, M. (2007). Voices on: Teachers and Teaching Assistants talk about Inclusion. International Journal of Inclusive Education, 11(3), 355-370.

Skogen, K. (2014). Innovasjon $i$ skolen kvalitetsutvikling og kompetanseheving [Innovation in the school quality development and competence]. Oslo: Universitetsforlaget.

Skogen, K. (2015). Skolelederens rolle i tilpasset opplæring [The school leaders role in Inclusive Education]. In J. Buli-Holmberg, S. Nilsen, \& Skogen, K. (Eds.) Kultur for tilpasset opplaering (pp. 33-43). Oslo: Cappelen Damm Akademisk.

Snowling, M. (2006). Developmental Reading Disorders. Journal of Child Psychology and Psychiatry, 32(1), 49-77. 
Stubbs, S. (2008). Inclusive Education Where there are few Resources. Oslo: Atlas Aliance.

Tangen, R. (2003). Skolelivskvalitet og elevkår - elevers egne erfaringer i møtet med videregående skole [School Quality of life and living conditions - pupils' own experiences in the face of high school]. In E. Befring, \& R. Tangen, (Eds.) Spesialpedagogikk (pp. 475-497). Oslo: Cappelen Damm.

Thomas, G., \& Loxley, A. (2001). Deconstructing Special Education and Constructing Inclusion. Buckingham: University Press.

Tomlinson, C.A., Brighton, C., Hertberg, H., Callahan, C.M., Moon, T.R., Brimijoin, K., Conover, L.A., \& Reynolds, T. (2003). Differentiating Instruction in Response to Student Readiness, Interest, and Learning Profile in Academically Diverse Classrooms: A Review of Literature. Journal for the Education of the Gifted, 27(2-3), 119-145.

UNESCO. (1994). The Salamanca Statement and Framework for Action on Special Needs Education. Paris. Retrieved from http://bit.ly/1FdHAPM.

UNESCO. (1948). Universal Declaration of Human Rights. Retrieved from http://bit. ly/18mukKq.

Vislie, L. (2003). From integration to inclusion: focusing global trends and changes in the Western European societies, European Journal of Special Needs Education, $18(1), 17-35$.

Willig, C. (2008). Introducing qualitative research in psychology: adventures in theory and method ( $2^{\text {nd }}$ ed.). Maidenhead: Open University Press.

Yin, R. K. (2003). Case study research: design and methods ( $3^{\text {rd }}$ ed.). California: Sage. 
